\title{
Diseases of groundnut in West Africa and their management: research priorities and stratiegies†
}

(Keywords: Groundnut, peanut, arachide, disease resistance, West Aírica.)

\author{
P. SUBRAHMANYAM $\neq$, D. C. GREENBERGł, S. SAVARYŞ and J. P. BOSCף
}

$\ddagger$ International Crops Research Institute for the Semi-Arid Tropics (ICRISAT) Sahelian Center, BP 12404, Niamey, Niger

Abstract. Diseases are major constraints to groundnut production in West Africa. Leaf spots, rust, rosetle and seeding diseases are present throughout most of the region and cause substantial losses in yield. Crop growth variability is a major yield-limiting factor in the Sahel. Aflatoxin contamination is a serious quality problem in the region. Strategies for management of these major diseases are briefly discussed with particular emphasis on the utilization of genetic resislance.

Résumé. En Af́rique de l'Ouest, les maladies sont l'une des principales contraintes de la production de l'arachide. Les cercosporioses, la rouille, la rosette et les maladies des plantules, présentes dans presque toule la région, causent des peries importantes de rendement. La variabilité de la croissance des cultures est l'un des principaux facleurs limitant celle production au Sahel. La contamination par les aflatoxines réduit la qualite de l'arachide cultivée dans la région. Les stratégies de lutte contre ces maladies sont brièvement présentèes, notamment l'utilisation de la résistance génètique.

\section{Introduction}

West Africa is the largest groundnut (Arachis hypogaea L.) producing region of Africa, contributing about $54 \%$ of the total groundnut production of the continent. The major groundnut producing areas are located around $12 \mathrm{~N}$ latitude (Figure 1). Senegal and Nigeria are the largest groundnut producers in West Africa, followed by Cameroon, Ghana, Gambia and Mali (Anonymous, 1987) (Table 1). The crop is grown to some extent in the other countries of the region including the humid rainforest areas. Groundnut is one of the most important cash and food crops in gross value of agricultural produce and export (Anonymous, 1982). Many countries in West Africa were major exporters of groundnut products to Europe in the past. However, in recent years, groundnut production in West Africa has declined drastically (Anonymous, 1982; Gillier, 1982).

The crop is grown aimost entirely by small-scale farmers under low crop production inpuls. The average yield of groundnut in West Africa is about $730 \mathrm{~kg}$ ha "1 (Anonymous, 1987). Some of the major constraints to groundnut production in West Africa are erratic rainfall patterns leading to severe drought at any stage of crop development, poor agronomic practices and epidemics of pests and diseases (Gillier, 1982; Cummins and Jackson, 1982; Anonymous, 1982). Fluctua- tions in the commercial market and low producer prices discourage farmers from growing groundnut. Allatoxin contamination lowers the quality of the produce, thus reducing its marketability and export value (Gillier, 1982).

\section{Diseases of groundnut in West Africa}

Diseases are major yield-limiting factors for groundnut in West Africa (Gillier, 1982; Cummins and Jackson, 1982). A number of fungal, viral and nematode diseases of groundnut have been reporled from West Africa (McDonald, 1969a; Merny et al., 1974; McDonald, 1978; Emechebe, 1980; Fauquet and Thouvenel, 1980; Germani, 1981; Dollet et al., 1986; Savary, 1987a; Khan and Misari, 1987; Baujard, 1988; Subrahmanyam et al., 1989) (Table 2). Most of the diseases are widespread in the region and may be considered as components of a multiple pathosystem (Savary et al., 1988), but only a few are economically important throughout the region. Information presented in this review has been obtained by systematic disease surveys in some countries, from personal contacts with groundnut scientists and from a literature search.

Leai spots, rust, rosette, and seedling rots are the most economically important diseases, and aflatoxin contamination is a serious quality problem of groundnut in West Africa. Crop growth variability is a major yield-limiting factor in sandy soils of the Sahel. Although pod rot, peanut clump, stem rot, charcoal rot, fusarium wilt and parasitic nematodes are serious in some countries, they are not regarded as diseases of regional importance. Diseases that are considered to be regionally important are leaf spois, rust, rosetle, seedling diseases, aflatoxins and crop growth variability, and these are being accorded high priority by national and/or international research institutions involved in the improvement of groundnut crop productivity in West Airica. The strategies for management of these major diseases are briefly discussed, with particular emphasis on utilization of genetic resistance.

\subsection{Foliar diseases}

2.1.1. Leaf spots. Both early leaf spot (Cercospora arachidicola Hori) and late leaf spot (Phaeoisariopsis

† Submitted as journal article No. 922 by the international Crops Research institute for the Semi-Arid Tropics (ICRISAT).

şıstitut International de Recherche Scientifique pour le Développement a Adiopodoumè (IIRSDA), B.P. V 51, Abidjan, Côte d'Ivoire.

II Instifut de Recherches pour les Huiles el Oléagineux (IRHO), BP 853, Bobo Dioulasso, Burkina Faso. 


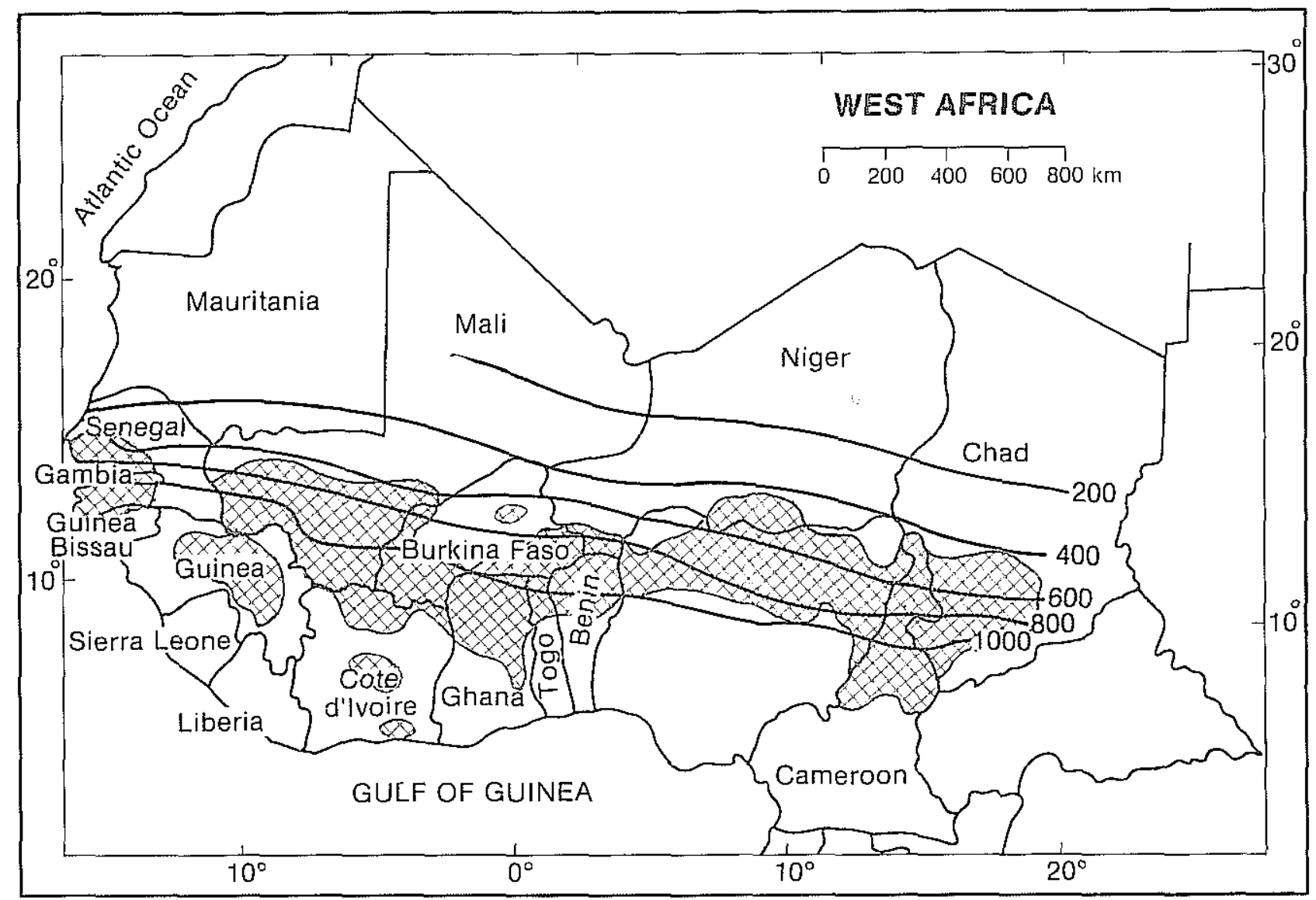

Figure 1. Distribution of major groundnut growing areas and rainfall isohyetes in West Africa.

personata (Berk. \& Curt.) v. Arx) are commonly present throughout West Africa wherever groundnut is grown. However, their relative importance varies between geographic locations and seasons, and is largely dependent on climatic factors (McDonald et al., 1985; Savary, 1987a). In general, early leat spot is predominant and destructive in high-rainfall areas (Guinea Savanna). However, there can be both short- and long-term fluctuations in the relative

Table 1. Area, production and yield of groundnut in some countries in West Africa in 1985

\begin{tabular}{|c|c|c|c|}
\hline Country & $\begin{array}{c}\text { Area } \\
(\times 1000 \text { ha })\end{array}$ & $\begin{array}{l}\text { Production } \\
(\times 1000 \mathrm{mt})\end{array}$ & $\begin{array}{l}\text { Yield } \\
(t \text { ha-1) }\end{array}$ \\
\hline Benin & 88 & 70 & 0.80 \\
\hline Burkina Faso & 200 & 77 & 0.39 \\
\hline Cameroon & 320 & 140 & 0.44 \\
\hline Chad & 170 & 80 & 0.47 \\
\hline Gôte d'lvoire & 85 & 80 & 0.94 \\
\hline Gambia & 100 & 120 & $1 \cdot 20$ \\
\hline Ghana & 117 & 128 & $1 \cdot 10$ \\
\hline Guinea & 130 & 75 & 0.58 \\
\hline Guinea Bissau & 85 & 30 & 0.35 \\
\hline Mali & 200 & 120 & 0.60 \\
\hline Niger & 100 & 40 & 0.40 \\
\hline Nigeria & 600 & 600 & 1.00 \\
\hline Senegal & 605 & 587 & 0.97 \\
\hline Sierra Leone & 14 & 14 & 1.00 \\
\hline Africa & 5284 & 4001 & 0.76 \\
\hline Wesl Airica & 2814 & 2161 & 0.73 \\
\hline
\end{tabular}

proportions of the two leaf spots within geographic locations. For instance, in Gaya, Niger, late leaf spot was predominant in 1986 and 1988 but early leal spot was predominant in 1987 (Subrahmanyam et al., 1989).

The pathogens may survive from season to season on volunteer and groundkeeper plants and in infected crop debris. No authentic host species are known outside the genus Arachis. Long-distance distribution of the pathogens may be by air-borne conidia, by movement of infected crop debris, or by movement of pods or seeds that are surface-contaminated with conidia or infected crop debris. There is no evidence of either pathogen being iniernally seedborne (McDonald et al., 1985).

Leaf spots damage the plant by reducing the available photosynthetic area by lesion formation, and by damaging the photosynthetic apparatus of neighbouring, apparently healthy tissues, they also stimulate leaflet abscission (Boote et al., 1983; Savary, 1987a). In addition to causing leaf spots, the two pathogens also produce lesions on petioles, stems and pegs. When disease attack is severe the affected leaflets first become chlorotic, then necrotic; lesions often coalesce; and leallets are shed (Smith, 1984).

2.1.2. Rust. Groundnut rust caused by Puccinia arachidis Speg. was recorded in the mid-1970s in almos! all groundnut growing areas in West Africa. Rust is very severe in southern parts of West Airica where rainiall is usually high (over $1000 \mathrm{~mm}$ ) (Sankara, 1987; Savary, 1987a). Rust also occurs in other groundnut growing areas of the region and may occasionally become severe depending on climatic 
Table 2. A checklist of groundnut diseases in West Africa

\section{Fungal diseases}

Aflaroot (Aspergillus flavus Link. ex. Fr.)

Alternaria leaf spol (Alternaria arachidis Kulk.)

Anthracnose (Colletotrichum capsici (Syd.) Butler \& Bisby)

Ascochyla leaf spot (Ascochyta arachidis Woronichin)

Charcoal rot (Macrophomina phaseolina (Tassi.) Goid.)

Gladosporium leat spot (Cladosporium sp.)

Cochliobolus leaf spol (Cochliobolus lunatus Nelson \& Harris)

Collar rot (Aspergillus niger van Tieg.)

Damping-off (Pythium myriotylum Drechs.)

Early leat spot (Cercosporz arachidicola Hori)

Fusarium wilt (Fusarium oxysporum Schlecht emend Sny. \& Hans)

Gloeosporium leaf spol (Gloeosporium sp.)

Grey spot (aetiology unknown)

Late leaf spot (Phaeoisariopsis personata (Berk. \& Curt.) v. Arx)

Leaf scorch and pepper spot (Leptosphaerufina crassiasca (Sechet) Jackson \& Bell)

Pestalotiopsis leaf spot (Pestalotiopsis adusta (Ell. 6 Ev.) Steyaert,

$P$. versicolor (Speg.) Steyaerl, P. arachidis Satya)

Phyllosticta leal spo! (Phyllosticta arachidis-hypogaea V. Rao)

Pleospora leaf spot (Pleospora infectoria Fck.)

Pod rol (Rhizoctonia solanj Kuhn, Macrophomina phaseolina

(Tassi.) Goid., Fusarium oxysporum Schlecht emend Sny. \& Hans,

F. solani (Mart.) Sacc.)

Pseudoplea leaf spol (Pseudoplea trifolii (Rosir.) Pelr.)

Rhizoctonia leaf blight (Rhizoctonia solani Khun)

Root rot (Rhizoctonia solani Kuhn)

Rust (Puccinia arachidis Speg.)

Seed and seedling rot (Aspergillus niger van Tieg., A. flavus link. ex. Fr., Botryodiplodia theobromae Pat., Cochliobolus bicolor Paul \& Par., Penicillium citrinum Thom., P. funiculosum Thom., Rhizopus spp., Fusarium spp., Pythium spp., Rhizoctonia solani Kuhn, Macrophomina phaseolina (Tassi.) Goid.

Stem rol (Sclerotium rolfsii Sacc.)

Web blotch (Didymella arachidicola (Chock) Taber, Peltit \& Philley)

Virus and mycoplasma diseases

Groundinut rosette (GRV, RAV)

Peanut clump (PCV-AG, PCV-AV)

Groundnut eyespol (GESV)

Groundnut crinkle (GCV)

Groundnut chlorotic spol (GCSV)

Tomato spotted wilt (TSWV)

Peanut moltle (PMV)

Groundnut streak (GSV)

Groundnut mosaic

Groundnut golden mosaic

Groundnut flecking

Cowpea mild moltle (CMMV)

Cucumber mosaic virus (CMV)

Witches' broom

\section{Nematode diseases}

Root-knol (Meloidogyne incognita (Kofoid \& White) Chitwood

Testa nematode (Aphelenchoides arachidis Bos)

Lesion nematode (Pratylenchus brachyurus (Godrey) Filipjev \& Schuurmans Steckhoven)

Chlorosis and stunting (Scutellonema cavenessi Sher and Aphasmatylenchus straturatus Germani)

Other nematodes: Species of Tylenchus. Ditylenchus, Tylenchorhynchus, Telotylenchus, Helicotylenchus, Rotylenchus, Hoplolaimus, Xiphinema, Longidorus. Trichodorus, Paratrichodorus, Trichotylenchus, Criconemella, Hemicycliophora, Filenchus, Coslenchus, Pratylenchus, Peltamigratus, Scutellonema, Hemicycliophora, Paratylenchus, Gracilacus, Aphelenchus, Macroposthonia and Siddiqia

\section{Bacterial disease}

Wilt (Pseudomonas solanacearum E. F. Smith)

Phanerogamic root parasile

Witch weed (Alectra vogelii Benth.) factors. Temperatures in the mid $20-30$ C range, free water on the leaf surface and high relative humidity favour infection and subsequent disease development (Savary, $1985 \mathrm{a}, \mathrm{b})$. It is not known if the fungus can produce spermagonia and aecia, or if any alternative host is involved in the life cycle (Subrahmanyam et al., 1985). There is no record of any hosts other than the genus Arachis, and no reliable evidence of groundnut rust being internally seed-borne or being spread by germplasm exchange (Subrahmanyam and McDonald, 1982). Urediniospores are short-lived. It is believed that the humid tropical zones of the Gulf of Guinea, where groundnut may be found throughout the year, serve as reservoirs of rust inoculum in West Africa (Savary, 1987b).

2.1.3. Management of foliar diseases. Rust and leaf spots are regarded as the most important among the fungal diseases of groundnut in West Africa. Yield losses are generally substantial when the crop is attacked by both leaf spots and rust. Field trials conducted over several years in Nigeria (Salako, 1987) using fungicides have clearly shown that losses from leaf spots and rust are substantial (Table 3). Results irom other locations in West Africa also indicate that leaf spots and rust cause substantial losses in pod yield (Table 4). Experiments where rust and leat spot diseases were set at various levels using combinations of fungicides indicated that, in high-input crops, losses increased faster with rust than with leaf spot severity (Savary et al., 1988; Figure 2).

Eradication of volunteer groundnut plants and groundkeeper is important in reducing the primary sources of rust and leaf spot inoculum. Crop rotation is useful in avoiding early-season infection by leaf spot pathogens (Subrahmanyam and McDonald, 1982; McDonald et al., 1985, Savary, 1986).

Table 3. Losses in pod yield of groundnut from leaf spots and rust in nigeria (from Salako, 1987)

\begin{tabular}{lrccc}
\hline Year & No. of trials & \multicolumn{2}{c}{ Pod yjeld $\left(\mathrm{t} \mathrm{ha}^{-1}\right)$} & $\begin{array}{c}\text { Percentage } \\
\text { yield } \\
\text { loss }\end{array}$ \\
\cline { 3 - 4 } & & Unsprayed & $\begin{array}{c}\text { Fungicidal } \\
\text { control }\end{array}$ & \\
\hline $1980-1981$ & 4 & 2.00 & $2 \cdot 81$ & 29 \\
$1981-1982$ & 12 & $1 \cdot 25$ & 2.59 & 52 \\
$1983-1984$ & 6 & 1.61 & 3.00 & 46 \\
$1984-1985$ & 6 & 1.87 & 3.37 & 45 \\
1986 & 3 & 1.28 & $2 \cdot 46$ & 48 \\
\hline
\end{tabular}

Table 4. Potential losses in pod yieids of groundnut from leaf spots and rust in West Africa

\begin{tabular}{lcl}
\hline Country & $\begin{array}{c}\text { Percentage } \\
\text { yield loss }\end{array}$ & \multicolumn{1}{c}{ Reference } \\
\hline Nigeria & 45 & Salako (1987) \\
Burkina Faso & 29 & Picasso (1987) \\
Niger & 24 & Subrahmanyam et al (1988) \\
Ghana & 20 & Atuahene-Amankwa et al. (1988) \\
Senegal & $30-40$ & Gautreau and De Pins (1980) \\
Cote d'lvoire & $40-70$ & Savary et al. (1989) \\
\hline
\end{tabular}




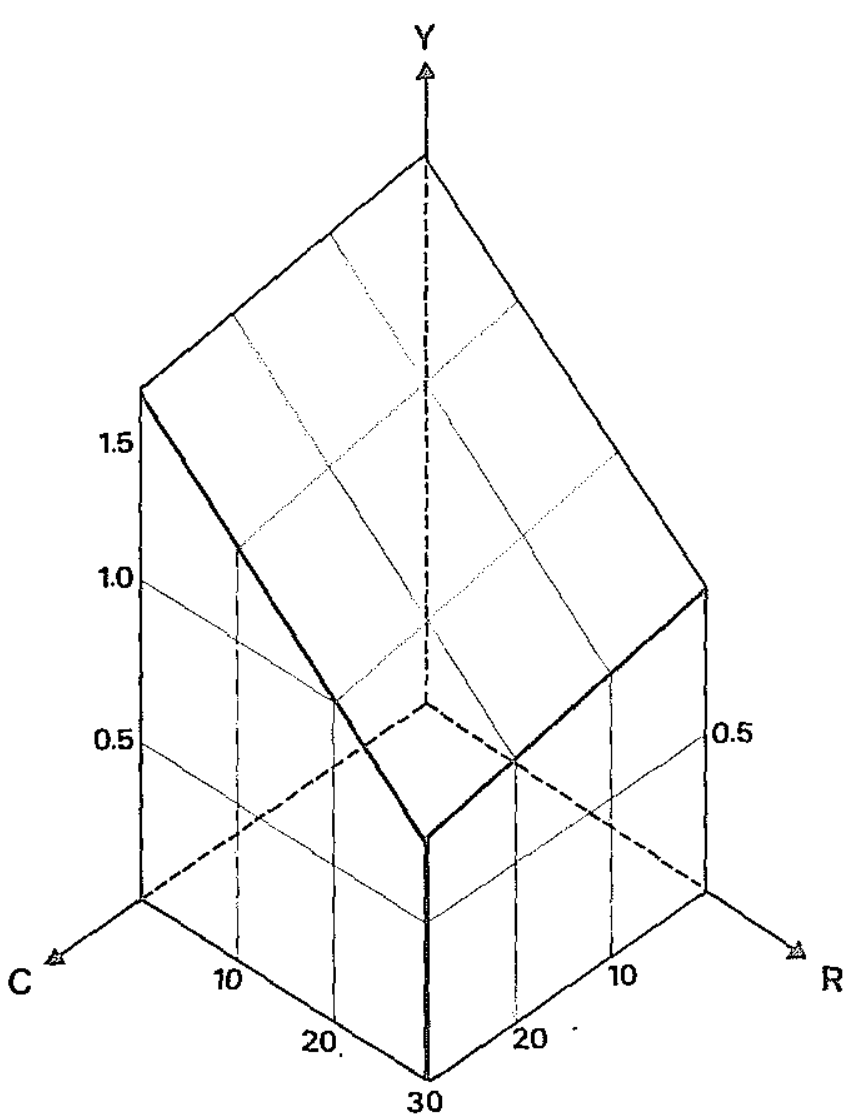

Figure 2. A regression plane $\left(Y=1771-27 \cdot 4 A-5 \cdot 8 C, R^{2}=0.95\right)$ of yield ( $Y$, in $\mathrm{kg} \mathrm{ha} \mathrm{h}^{-1}$ ) on rust ( $A$ ) and lealspot (C) severity (\%) from an experiment on crop loss assessment in groundnut (from Savary et al., 1988).

Leaf spots and rust can be controlled by the application of certain fungicides (McDonald and Fowler, 1976: Salako, 1987; Picasso, 1987). It is doubtful that at the present time fungicide spraying is economically feasible for small-scale farmers in West Aírica. Hence, developing resistant cultivars is one of the best means of reducing crop losses from these diseases, and is particularly well suited to small-scale farmers of West Africa, who generally lack the financial resources, logistic means, and technical expertise required for chemical control. Almost all groundnut varieties currently grown by farmers in West Africa are susceptible to leaf spots and rust (Table 5). In recent years, screening the world collection of groundnut germplasm at ICRISAT (Internationaf Crops Research Institute for the Semi-Arid Tropics) Center, India, has resulted in the identification of several sources of resistance to rust and late leaf spot (Tables 6 and 7) (Subrahmanyam et al., 1982, 1983, 1985; McDonatd et al., 1985: Subrahmanyam and McDonald, 1987). Some of these sources of resistance were evaluated through multilocational trials in West Africa and the resistance to rust and late leai spot was found to be stable (Table 8) (Sankara, 1987). In addition, some cultivated genotypes have shown partial resistance in specifically designed experiments (Savary and Zadoks, 1989). Transferring resistance to these diseases into agronomically acceptable varieties is being carried out at ICRISAT Center, and cultivars with acceptable levels of resistance to rust and late leaf spot have been bred (Reddy et al., 1987). They include derivatives of interspecific
Table 5. Recommended groundnut varieties and their reactions to principal diseases in West Africa

\begin{tabular}{lllll}
\hline Cariely & $\begin{array}{c}\text { Cycle } \\
\text { (days) }\end{array}$ & \multicolumn{2}{c}{ Disease reactiona } \\
\hline & $\begin{array}{c}\text { Early Late Rust Roselle Aspergillus } \\
\text { leaf leaf } \\
\text { spot spot }\end{array}$ & $\begin{array}{c}\text { flavus } \\
\text { spot }\end{array}$ \\
\hline
\end{tabular}

\begin{tabular}{lrrrrr}
\hline $\begin{array}{l}\text { Spanish } \\
55-437\end{array}$ & 90 & $\mathrm{~S}$ & $\mathrm{~S}$ & $\mathrm{~S}$ & $\mathrm{~S}$ \\
CN 49 C & 90 & $\mathrm{~S}$ & $\mathrm{~S}$ & $\mathrm{~S}$ & $\mathrm{~S}$ \\
TE 3 & 90 & $\mathrm{~S}$ & $\mathrm{~S}$ & $\mathrm{~S}$ & $\mathrm{~S}$ \\
TS 32-1 & 90 & $\mathrm{~S}$ & $\mathrm{~S}$ & $\mathrm{~S}$ & $\mathrm{~S}$ \\
KH 149 A & 90 & $\mathrm{~S}$ & $\mathrm{~S}$ & $\mathrm{~S}$ & $\mathrm{R}$ \\
KH 241 O & 90 & $\mathrm{~S}$ & $\mathrm{~S}$ & $\mathrm{~S}$ & $\mathrm{R}$ \\
QH 243 C & 90 & $\mathrm{~S}$ & $\mathrm{~S}$ & $\mathrm{~S}$ & $\mathrm{R}$ \\
$73-30$ & 95 & $\mathrm{~S}$ & $\mathrm{~S}$ & $\mathrm{~S}$ & $\mathrm{~S}$ \\
796 & 90 & $\mathrm{~S}$ & $\mathrm{~S}$ & $\mathrm{~S}$ & $\mathrm{~S}$ \\
$47-10$ & 90 & $\mathrm{~S}$ & $\mathrm{~S}$ & $\mathrm{~S}$ & $\mathrm{~S}$ \\
Georgia & 110 & $\mathrm{~S}$ & $\mathrm{~S}$ & $\mathrm{~S}$ & $\mathrm{~S}$ \\
Philippine & 90 & $\mathrm{~S}$ & $\mathrm{~S}$ & $\mathrm{~S}$ & $\mathrm{~S}$ \\
$\quad$ Pink & & & & &
\end{tabular}

$\begin{array}{lccccc}\begin{array}{l}\text { Virginis } \\ 69-101\end{array} & 120 & \mathrm{~S} & \mathrm{~S} & \mathrm{~S} & \mathrm{R} \\ 59-426 & 120 & \mathrm{~S} & \mathrm{~S} & \mathrm{~S} & \mathrm{R} \\ \text { RMP } 91 & 150 & \mathrm{~S} & \mathrm{MR} & \mathrm{S} & \mathrm{R} \\ \text { RMP 12 } & 150 & \mathrm{~S} & \mathrm{MR} & \mathrm{S} & \mathrm{R} \\ 73-33 & 110 & \mathrm{~S} & \mathrm{~S} & \mathrm{~S} & \mathrm{~S} \\ 28-206 & 120 & \mathrm{~S} & \mathrm{~S} & \mathrm{~S} & \mathrm{~S} \\ 57-313 & 125 & \mathrm{~S} & \mathrm{~S} & \mathrm{~S} & \mathrm{~S} \\ 57-422 & 110 & \mathrm{~S} & \mathrm{~S} & \mathrm{~S} & \mathrm{~S} \\ \text { GH } 119-20 & 110 & \mathrm{~S} & \mathrm{~S} & \mathrm{~S} & \mathrm{~S} \\ 756 \mathrm{~A} & 125 & \mathrm{~S} & \mathrm{~S} & \mathrm{~S} & \mathrm{~S} \\ 73-27 & 125 & \mathrm{~S} & \mathrm{~S} & \mathrm{~S} & \mathrm{~S} \\ 73-28 & 125 & \mathrm{~S} & \mathrm{~S} & \mathrm{~S} & \mathrm{~S} \\ 47-16 & 120 & \mathrm{~S} & \mathrm{~S} & \mathrm{~S} & \mathrm{~S} \\ 59-127 & 120 & \mathrm{~S} & \mathrm{~S} & \mathrm{~S} & \mathrm{~S} \\ \text { Mami Pintar } & 125 & \mathrm{~S} & \mathrm{~S} & \mathrm{~S} & \mathrm{~S}\end{array}$

Valencia

$\begin{array}{llllll}\text { A } 124 \mathrm{~B} & 90 & \mathrm{~S} & \mathrm{~S} & \mathrm{~S} & \mathrm{~S}\end{array}$

${ }^{2} S=$ Susceptible, $M R=$ moderately resistant and $R=$ resistant.

hybrids between Arachis hypogaea and A. cardenasii. Some breeding lines have given promising yields in a preliminary triaf in Niger (Table 9).

Several sources of resistance to early leat spot have been identified in the USA (see McDonald et al., 1985) but their performance in various agroecological situations in Wesi Africa has yet to be established. In recent years screening of a large collection of groundnut germplasm lines has resulted in identification of some useiul levels of resistance to early leas spol at ICRISAT Center, India and SADCC/ICRISAT, Malawi (Waliyar et al., 1988).

\subsection{Rosette}

Groundnut rosette disease was first observed in Tanzania (Zimmerman, 1907) and was subsequently recorded in many African countries. The disease is apparently restricted to Africa, south of the Sahara. Two types of groundnut rosette diseases, chlorotic rosette and green rosette, are distinguished on the basis of their foliar symptoms. A mosaic 
Table 6. Sources of resistance to Puccinia arachidis available from ICRISAT (from Subrahmanyam and MCDonald, 1982)

\begin{tabular}{|c|c|c|c|c|}
\hline Genolype & $\begin{array}{l}\text { ICG } \\
\text { No: }\end{array}$ & $\begin{array}{c}\text { Botanical } \\
\text { type/variety }\end{array}$ & $\begin{array}{c}\text { Seed } \\
\text { colour }^{\text {s }}\end{array}$ & $\begin{array}{c}\text { Country of } \\
\text { origin }\end{array}$ \\
\hline NC AC 17090 & 1697 & fastigiata & Light tan & Peru \\
\hline EC 76446 (292) & 2716 & fastigiata & Purple & Uganda \\
\hline PI 259747 & 4747 & fastigiata & Purple & Peru \\
\hline NC Ac 927 & 6022 & fastigiata & Purple & Sudan \\
\hline P| 350680 & 6340 & fastigiata & Purple & Honduras \\
\hline NC Ac 17133-RF & 7013 & fastigiata & Purple & Peru \\
\hline PI 215696 & 7881 & fastigiata & Purple & Peru \\
\hline PI 314817 & 7882 & fastigiata & Light tan & Peru \\
\hline PI 315608 & 7883 & hypogaea & Off-white & Israel/USA \\
\hline PI 341879 & 7884 & fastigiata & Purple & Peru \\
\hline PI 381622 & 7885 & fastigiata & Purple & Peru \\
\hline PI 390593 & 7886 & fastigiata & Light tan & Peru \\
\hline PI 390595 & 7887 & fastigiata & Purple & Peru \\
\hline PI 393517 & 7889 & fastigiata & Off-White & Peru \\
\hline PI 393527-B & 7892 & hypogaea & Red & Peru \\
\hline PI 393641 & 7894 & fastigiata & $\begin{array}{l}\text { Light tan } \\
\text { with purple } \\
\text { stripes }\end{array}$ & Peru \\
\hline PI 393643 & 7895 & fastigiata & Light tan & Peru \\
\hline PI 393646 & 7896 & fastigiata & Purple & Peru \\
\hline PI 405132 & 7897 & fastigiata & Purple & Peru \\
\hline PI 407454 & 7898 & fastigiata & Tan & Ecudor \\
\hline PI 414331 & 7899 & hypogaea & Tan & Honduras \\
\hline PI 414332 & 7900 & hypogaea & Tan & Honduras \\
\hline
\end{tabular}

aICRISAT Groundnut Accession Number.

${ }^{\circ}$ RHS colour chart. Royal Horticultural Society, London, 1966.

Table 7. Genotypes resistant to Phaeoisariopsis personata available from ICRISAT (from MCDonald et al., 1985)

\begin{tabular}{lllll}
\hline Genotype & $\begin{array}{c}\text { ICG } \\
\text { No. }\end{array}$ & $\begin{array}{c}\text { Botanical } \\
\text { type/variety }\end{array}$ & $\begin{array}{c}\text { Seed } \\
\text { colour }^{\mathrm{b}}\end{array}$ & $\begin{array}{c}\text { Country of } \\
\text { origin }\end{array}$ \\
\hline EC 76446 (292) & 2716 & fastigiata & Purple & Uganda \\
USA 63 & 3527 & fastigiata & Purple & USA \\
PI 259747 & 4747 & fastigiata & Purple & Peru \\
PI 350680 & 6340 & fastigiata & Purple & Honduras \\
NC AC 17133-RF & 7013 & fastigiata & Purple & Peru \\
PI 215696 & 7881 & fastigiata & Purple & Peru \\
PI 351879 & 7884 & fastigiata & Purple & Peru \\
PI 381622 & 7885 & fastigiata & Purple & Peru \\
PI 390595 & 7887 & fastigiata & Purple & Peru \\
PI 405132 & 7897 & fastigiata & Purple & Peru \\
\hline
\end{tabular}

${ }^{a}$ ICRISAT Groundnut Accession Number.

'Based on the RHS colour chart. Royal Horticultural Society, London, 1966.

rosette has also been reported from southern Africa. Green rosette is usually prevalent in West Africa whereas chlorotic rosette is more common in East and Central Africa. Groundnut rosette is transmitted by several species of aphids (Gibbons, 1977; Fauquet and Thouvenel, 1980; Reddy, 1984).

Groundnut rosette is well recognized as one of the major constraints of groundnut production in West Africa (Fauquet and Thouvenel, 1980). Although the rosette epidemics in West Africa are sporadic, yield losses are substantial
Table 8. Rust reactions of some groundnut genotypes in India and Burkina Faso

\begin{tabular}{|c|c|c|c|}
\hline \multirow{2}{*}{$\begin{array}{l}\text { ICG } \\
\text { No. }{ }^{a}\end{array}$} & \multirow[t]{2}{*}{ Genotype } & \multicolumn{2}{|c|}{ Rust scores ${ }^{b}$} \\
\hline & & Indiac & Burkina Faso \\
\hline \multicolumn{4}{|c|}{ Resistant genotypes } \\
\hline 1697 & NC Ac 17090 & $2 \cdot 2$ & $2 \cdot 0$ \\
\hline 1704 & NC AC 17129 & $3 \cdot 8$ & $4 \cdot 0$ \\
\hline 1707 & NC AC 17132 & $3 \cdot 8$ & $2 \cdot 5$ \\
\hline 2716 & EC 76446 (292) & $2 \cdot 8$ & $2 \cdot 1$ \\
\hline 4746 & PI 298115 & $4 \cdot 0$ & $3 \cdot 0$ \\
\hline 4747 & PI 259747 & $3 \cdot 0$ & $2 \cdot 2$ \\
\hline 6022 & NC Ac 927 & $3 \cdot 6$ & $3 \cdot 3$ \\
\hline 6340 & PI 350680 & $3 \cdot 0$ & $2 \cdot 3$ \\
\hline 7013 & NC Ac $17133(\mathrm{RF})$ & $3 \cdot 3$ & $3 \cdot 2$ \\
\hline 7881 & PI 215696 & $3 \cdot 3$ & $4 \cdot 2$ \\
\hline 7882 & PI 314817 & 30 & $2 \cdot 3$ \\
\hline 7884 & PI 341879 & $2 \cdot 5$ & $2 \cdot 1$ \\
\hline 7885 & PI 381622 & $3 \cdot 0$ & $2 \cdot 0$ \\
\hline 7886 & PI 390593 & $2 \cdot 8$ & $2 \cdot 0$ \\
\hline 7887 & PI 390595 & 3.5 & $2 \cdot 0$ \\
\hline 7888 & PI 393516 & $4 \cdot 3$ & $4 \cdot 0$ \\
\hline 7889 & PI 393517 & $3 \cdot 2$ & $2 \cdot 0$ \\
\hline 7890 & PI 393529 & $4 \cdot 2$ & $2 \cdot 1$ \\
\hline 7892 & PI 393527-B & $3 \cdot 0$ & $2 \cdot 0$ \\
\hline 7893 & PI 393531 & $3 \cdot 4$ & $2 \cdot 0$ \\
\hline 7894 & PI 393641 & 3.8 & $2 \cdot 3$ \\
\hline 7895 & PI 393643 & 3.0 & $2 \cdot 0$ \\
\hline 7896 & PI 393646 & $2 \cdot 4$ & $2 \cdot 0$ \\
\hline 7897 & PI 405132 & $2 \cdot 4$ & $2 \cdot 0$ \\
\hline 7898 & PI 407454 & $2 \cdot 8$ & $2 \cdot 0$ \\
\hline 7899 & PI 414331 & $2 \cdot 8$ & $2 \cdot 0$ \\
\hline 7900 & PI 414332 & $2 \cdot 4$ & $3 \cdot 3$ \\
\hline \multicolumn{4}{|c|}{ Susceptible genotypes } \\
\hline 4580 & EC 76446 & $9 \cdot 0$ & $8 \cdot 5$ \\
\hline 6446 & NC 3033 & $9 \cdot 0$ & $8 \cdot 3$ \\
\hline 221 & TMV 2 & 90 & $9 \cdot 0$ \\
\hline 799 & Robut 33-1 & $9 \cdot 0$ & $8 \cdot 6$ \\
\hline
\end{tabular}

"ICRISAT groundnut accession number.

${ }^{b}$ Rust scores on a nine-point scale (Subrahmanyam et al., 1982).

"Mean rust scores of 1979-1982 field screening trials at ICRISAT Center, Palancheru, Andhra Pradesh, India.

"Rust scores of 1983 field screening trials at the Agricultural Research Station, Niangoloko, Burkina Faso.

Table 9. Pod and haulm yields of six groundnut breeding lines resistant to late leaf spot and rust diseases in a preliminary field trial during the 1988 rainy season in Niger

\begin{tabular}{lcr}
\hline Breeding line & \multicolumn{2}{c}{ Yield $\left(\mathrm{t} \mathrm{ha}^{-1}\right)$} \\
\cline { 2 - 3 } & Pod & Haulms \\
\hline ICGV 87185 (ICG (FDRS) 70) & $2 \cdot 23$ & 4.04 \\
ICGV 87156 (ICG (FDRS) 2) & 2.23 & 4.40 \\
ICGV 87183 (ICG (FDRS) 42) & $2 \cdot 21$ & 4.35 \\
ICGV 87160 (ICG (FDRS) 10) & $2 \cdot 12$ & 4.02 \\
ICGV 87172 (ICG (FDRS) 28) & 2.01 & 5.10 \\
ICGV 87157 (ICG (FDRS) 4) & 1.95 & 5.08 \\
Controls & & \\
55-437 & 1.49 & 3.22 \\
28-206 & 1.51 & 4.53 \\
$\quad$ SE & \pm 0.15 & \pm 0.51 \\
CV (\%) & 16 & 20 \\
\hline
\end{tabular}


whenever the disease occurs in epidemic proportions. The 1975 rosette epidemic in some West African countries is a good example. In Nigeria about 0.7 million ha of the crop were destroyed incurring a loss of over $N$ (Naira) 137 million (Yayock et al., 1976). In the same year in Niger, groundnut production was reduced by almosi $80 \%$ with an average yield of $131 \mathrm{~kg} \mathrm{ha}^{-1}$ as compared with yields in previous years (Anonymous, 1987; Subrahmanyam et al., 1989). In subsequent years in Niger, although groundnut rosette occurred sporadically, the disease attained epidemic proportions only in 1987 (Subranmanyam et al., 1988). The reasons for these flucluations in rosette epidemics in West Africa are not fully understood. Further studies on the viruses, the vector, and their interaction with the environment are necessary to understand the epidemiology of groundnut rosette, to forecast epidemic outbreaks, and to formulate suitable management practices.

Groundnut rosette can be managed by controlling the vectors using insecticicles. Careful monitoring of aphid infestation and timely application of insecticides are important to achieve satisfactory control of groundnut rosette. Chemical control may not be economically leasible to resource-limited farmers in West Africa. Early planting at high plant density can significantly reduce disease incidence. Eradication of volunteer groundnut plants and groundkeepers may be useful in preventing the perpetuation of virus inoculum during the off-season (Reddy, 1984).

Pioneering research on development of groundnut cultivars with resistance to rosette was done by the IRHO (Institut de Recherches pour les Huiles et Oleagineux) in West Africa. Sources of resistance to rosetle were first discovered in 1952 afler an epidemic of the disease almost completely destroyed a large collection of groundnut germplasm al Bambey, Senegal (Catherinet et al. 1954). However, a few germplasm lines originating from the frontier region between Burkina Faso and Côte d'Ivoire were able to withsland the epidemic. These sources formed the basis for rosette resistance breeding programmes throughout Africa. Cultivars with acceptable levels of yield and rosette resistance were bred in Burkina Faso, Senegal, Nigeria, Malawi and to a limited extent in other countries (Dhery and Gillier, 1971; Gibbons and Mercer, 1972; Gillier and Bockelee-Morvan, 1975; Gillier, 1978; Gautreau and De Pins, 1980; Misari et al., 1980; Soumano and Diallo, 1982; Harkness and Salako, 1982; Bockelee-Morvan, 1983; Nigam, 1987; Bock, 1987; Soumano and Traore, 1988; N'Diaye, 1988; Misari et al., 1988). In the early years the rosette-resistant cultivars bred were long cycle (120-150 days) Virginia types (e.g., RMP 91, RMP 21, 69-101 and 59-426) (Table 5), suitable for cultivation only in the wetter Guinea Savanna region of West Africa. However, in receni years short cycle (90 days) Spanish types (e.g. KH 149 A, KH 241 D and QH 243 C) (Table 5) have been bred for cultivation in the dry Sahel-Sudanian region of West Africa. Unfortunately, most of these roselte-resistant cultivars are susceptible to leaf spots and rust. Combining rosette resistance with late leat spot and rust resistances in short-medium cycle (90-115 days) material is important for the Sahel-Sudanian region, and such material would also be valuable for the weller regions where farmers oiten wish to plant groundnut late after completion of weeding in the cereal crops, but cannot do this as current high-yielding short-cycle varieties are susceptible to all these diseases. Obtaining such combinations will be difficult, but attempts have already been made. The rosette-resistant, short-cycle varieties from the $\mathrm{IRHO}$ such as KH $194 \mathrm{~A}$, and rust and late leaf spol-resistant varieties from ICRISAT Center should be useful as parents. RG 1 (bred in Malawi) is another possible source of rosette resistance in late malerial; its seed type is somewhat more acceplable as an edible nut than RMP 12.

\subsection{Seedling disenses}

Young seedlings are attacked by a variety of seed- and soil-borne fungi including Aspergillus flavus Link. ex Fr., $A$. niger van Tiegh., Botryodiplodia theobromae Pat., Cochliobolus bicolor Paul \& Par., Rhizoctonia solani Kuhn., Macrophomina phaseolina (Tassi.) Goid., species of Penicillium, Rhizopus, Fusarium and Pythium, resulting in pre-emergence mortality. The infected seedlings are reduced to a shrivelled, dark brown or black spongy mass of rotied tissue covered with a mat of mycelium on which masses of iructifications are produced. Decay is most rapid when infected seeds are planted, and the fungus becomes active as the seeds hydrate. Post-emergence seedling diseases include collar/crown rot ( $A$. niger), aflaroot ( $A$. flavus) and root rot ( $A$. solani, $M$. phaseolina and Pythium spp.).

Seedling diseases are present throughout West Africa wherever groundnut is grown, and are particularly serious when poor-qualify seed is used for planting. Severe fluctuations in soil moisture soon after planting, which are common in West Africa, may lead to high incidence of seedling diseases. Disease surveys carried out in Niger in 1987 (Subrahmanyam et al., 1989) and in Côte d'lvoire in 1983-85 (Savary, 1987b) have shown that reduction in plant stand due to seedling diseases is severe in many farmers' fields. Field trials conducted at three locations in Niger in 1987 using seed-protectant chemicals showed a high reduction in plant stand on non-treated plots due to seedling diseases: Sadoré (27\%), Bengou (23\%) and Maradi (26\%). The losses in pod yields were $24 \%$ in Sadore, $19 \%$ in Maradi, and $4 \%$ in Bengou. Although there was considerable reduction in plant stand in Bengou, the yield loss was only $4 \%$ because of vigorous plant growth compensating the yield. Such a compensation is not to be expected in farmers' fields, where the seed rate is usually very low. Yield losses from seedling diseases are substantial in low-fertility areas and when the crop is subjected to drought resulting in poor crop growth.

Seedling diseases can be to some extent controlled by using high-quality seed for planting. Deep planting should be avoided as etiolated seedlings are highly susceptible to these pathogens. There is abundant literature on the use of seed-protectant chemicals for controlling seedling diseases of groundnut in West Africa. Field irials have been conducted in many locations in West Africa and a number of fungicides were found to be useful. Recommendations have been made to the farmers on the use of seed-protectanl fungicides or mixtures of fungicide and insecticide. 
Sources of resistance to collar rot (e.g. U4-47-7) and aflaroot (e.g. J 11) are also available, but at the present time breeding efforts to transfer these resistances into cultivars agronomically acceptable in West Africa may not be immediately required, since seed treatment with fungicides is simple and economical and is already being done by a reasonable proportion of farmers in some parts of West Africa.

\subsection{The aflatoxin problem}

Contamination of groundnut with aflatoxins, the secondary toxic metabolites produced by fungi of the Aspergillus flavus group, is a serious quality problem in many paris of West Africa. A. flavus may invade groundnut seeds before harvest, during post-harvest drying, and during storage if the seeds are rewelled. Invasion of seeds by $A$ flavus and aflatoxin production can be minimized by crop rotation, prevention of drought stress by supplemental irrigation, harvesting at optimum maturity, drying pods under appropriate temperature and air-flow conditions, and storage of produce at low moisture content and in insect-iree conditions (McDonald, 1966; McDonald and Harkness, 1967; Pettit and Taber, 1968; McDonald, 1969b; Subrahmanyam and Rao, 1974; Pettit, 1985). However, from the continued high levels of contamination reported, especially from the SAT (semi-arid tropics) countries, it appears that farmers have not yet adopted these recommendations (Mehan and McDonald, 1984). It has therelore become necessary to investigate the possibilities of genetic resistance in the hope of developing cultivars with seeds which A. flavus cannot invade or which, if invaded, do not support aflatoxin production.

In recent years, several laboratory and field screening techniques have been developed to screen groundnut for resistance to A. flavus infection and/or aflatoxin production. Several genotypes with resistance to seed invasion in the field and also in in vitro inoculation tests in the laboratory have been reported (Mixon, 1979; Mehan ei al., 1982; Mehan and McDonald, 1984) (Table 10). Some genotypes support only very low levels of aflatoxin production when seeds were invaded by $A$. flavus. Of the groundnut lines with resistance to A. flavus, J 11 and $\mathrm{AH} 7223$ have shown reasonable agronomic performance in preliminary field trials in Niger. Progress has been made in developing breeding lines with

Table yo. Sources of Resistance to colonization of rehydrated stored seed by Aspergillus flavus

\begin{tabular}{lll}
\hline Genotype & \multicolumn{1}{c}{$\begin{array}{c}\text { Botanica! } \\
\text { type }\end{array}$} & \multicolumn{1}{c}{$\begin{array}{c}\text { Seed } \\
\text { colour }\end{array}$} \\
\hline AH 7223 & $\begin{array}{l}\text { Spanish } \\
\text { J11 }\end{array}$ & $\begin{array}{l}\text { Salmon } \\
\text { Spanish }\end{array}$ \\
Var 27 & Valencia & Salmon \\
UF 71513 & Valencia & Red \\
U4-47-7 & Spanish & Salmon \\
U1-2-1 & Virginia bunch & Light Salmon \\
Faizpur & Valencia & San \\
$55-437$ & Spanish & Tan \\
$73-30$ & Spanish & Salmon \\
$73-33$ & Virginia bunch & Pink \\
\hline
\end{tabular}

stable resistance to seed colonization and with acceptable yield and quality. It is worth noting that the variety 55-437, grown in many countries in West Africa, has shown seed resistance to $A$. flavus invasion in both field and laboratory tests (Zambettakis et al., 1977). This variety is being crossed with $J 11$ as the start of a breeding program for A. flavus resistance at ICRISAT Sahelian Center, Niger. Some breeding lines with $A$. flavus resistance from ICRISAT Center have also shown promising agronomic performance in a preliminary trial in Niger (Table 11).

\subsection{Crop growth variability}

Variation in crop growth is a major limiting factor for groundnut production in the Sahel. During our surveys in Niger in 1986 and 1987, we observed large variations in crop growth in farmers' fields, especially in sandy soils, in all major groundnut producing areas of the country. Affected plants were usually present in patches intermixed with apparently healthy plants. These paiches were always randomly distributed in the field irrespective of the field contour (Subrahmanyam et al., 1988).

Three distinct types of symptoms were observed on affected plants:

1. Plants severely stunted, chlorotic, with poor shool and root development. Necrosis of roots severe with shredding of cortex tissues. Pods few in number with necrotic lesions on surfaces. Plant mortality evident in many cases.

2. Plants severely stunted, bushy, dark green with mild mosaic symptoms on young leaves. Planis become chlorotic towards maturity.

3. Plants severely stunted (as in category 1) but older leaves showing black necrotic lesions on margins.

The relative incidence of plants showing the above symptoms varies over locations. The factors contributing to variation in crop growth are not yet fully elucidated.

Table 11. Pod and haulm yields of six groundnut breeding lines with seed resistant to Aspergillus flavus in a preliminary field trial during the 1988 rainy season in Niger

\begin{tabular}{lcr}
\hline Breeding line & \multicolumn{2}{c}{ Yield $\left(\mathrm{t} \mathrm{ha}^{-1}\right)$} \\
\cline { 2 - 3 } & Pods & Hauims \\
\hline ICGV 87088 & $2 \cdot 82$ & $3 \cdot 07$ \\
ICGV 87118 & $2 \cdot 65$ & $3 \cdot 23$ \\
ICGV 87078 & $2 \cdot 58$ & $2 \cdot 22$ \\
ICGV 87104 & $2 \cdot 57$ & $3 \cdot 22$ \\
ICGV 86168 & $2 \cdot 56$ & $2 \cdot 81$ \\
ICGV 87087 & $2 \cdot 50$ & $2 \cdot 41$ \\
Controls & & \\
TS 32-1 & $2 \cdot 39$ & $2 \cdot 11$ \\
55-437 & $2 \cdot 24$ & $2 \cdot 32$ \\
JL 24 & $1 \cdot 89$ & $2 \cdot 23$ \\
J 11 & $1 \cdot 51$ & $+\cdot 83$ \\
SE & \pm 0.15 & $\pm 0 \cdot 21$ \\
CV $(\%)$ & 12 & 16 \\
\hline
\end{tabular}


2.5.1 Occurrence of peanut clump and parasitic nematodenes. Peanut clump virus (PCV) particles were observed in ultra-thin sections of leaves collecled trom bushy, dark green, stunted plants present in patches. The PCV was found to be serologically related to Indian and West African PCV isolates by ELISA (enzyme-linked immunosorbent assay) tests. Reactions on various indicator hosts in artificial inoculation also clearly showed the presence of PCV. PCV is definitely one of the factors contributing to the variation in crop growth.

Analysis of soil samples colfected from rhizosphere and geocarposphere zones, and of the roots of affected plants, showed high populations of plant parasitic nematodes, especially Scutellonema clathricaudatum Whitehead, Xiphinema attorodorum Luc, and Telotylenchus indicus Siddiqi. These seem to be major contributing factors to crop growth variability in groundnut. However, the relative importance of PCV, plant parasitic nematodes, and their interaction in crop growth variability in groundnut in the Sahel has still to be established.

2.5.2. Effect of pesticides. Soil treatment with carbofuran especially at high doses $\left(8-10 \mathrm{~kg}\right.$ a.i. $\mathrm{ha}^{-1}$ ) was effective in reducing nematode populations and the variation in crop growth. Plants in carbofuran-treated plots showed normal growth, whereas in control plots, plants were severely stunted and chlorolic. There was a three-fold increase in pod yields and a two-fold increase in haulm yields following carbofuran treatment (10 kg a.j. ha " ${ }^{1}$ ) (Subrahmanyam et al., 1988).

Further trials conducted at Sadore, Niger, indicated that soil treatment with carbofuran (10 kg a.i. ha $\left.{ }^{1}\right)$ and farmyard manure (FYM) (10 t ha" ${ }^{1}$ ) was extremely satisfactory in reducing nematode populations and variation in crop growth, and in increasing yields (Table 12). Soil treatment with FYM alone was not efiective (Subrahmanyam et al., 1988).

The efficacy of four pesticides (dibromochloropropane, dazomet, carboluran and aldicarb) in controlling variation in crop growth was investigated both under rainfed and irrigated conditions. Dibromochloropropane was most effective in reducing nematode populations and variation in crop growth, and increasing pod and haulm yields under irrigation. Aldicarb was most effective under rainfed conditions (Table 13). Plots treated with dibromochloropropane (irrigated conditions) and aldicarb (rainfed conditions) showed vigorous plant growth, as assessed by plant height, root length and number of leaves on the main

Table 12. Effect of carbofuran and farmyard manure on plant height and yield of groundnut (cv. 55-437) at Sadore, Niger, rainy season 1987 (from Subrahmanyam et al., 1988)

\begin{tabular}{|c|c|c|c|c|c|c|}
\hline \multirow[t]{3}{*}{ Treatment $\mathrm{t}^{\mathrm{a}}$} & \multicolumn{2}{|c|}{ Plant height (cm) } & \multicolumn{4}{|c|}{ Yield (t ha $\left.{ }^{-1}\right)$} \\
\hline & \multirow[t]{2}{*}{ Irrigated } & \multirow[t]{2}{*}{ Rainfed } & \multicolumn{2}{|c|}{ Irrigated } & \multicolumn{2}{|c|}{ Rainfed } \\
\hline & & & Pods & Haulms & Pods & Haulms \\
\hline $\begin{array}{l}\text { Carbofuran }+ \\
\text { farmyard manure }\end{array}$ & 25 & 16 & $3 \cdot 04$ & $2 \cdot 55$ & $1 \cdot 75$ & $1 \cdot 23$ \\
\hline Carboluran & 21 & 15 & $2 \cdot 14$ & $1 \cdot 30$ & $1 \cdot 67$ & 1.05 \\
\hline Farmyard manure & 14 & 10 & $1 \cdot 10$ & 1.03 & $0 \cdot 78$ & 0.70 \\
\hline Control & 11 & 8 & 0.84 & 0.80 & $0 \cdot 66$ & 0.61 \\
\hline SE & \pm 2 & \pm 1 & \pm 0.20 & $\pm 0 \cdot 14$ & $\pm 0 \cdot 10$ & \pm 0.06 \\
\hline CV $(\%)$ & 24 & 22 & 27 & 25 & 16 & 14 \\
\hline
\end{tabular}

${ }^{a}$ Carboluran (10 kg a.i. ha $\left.{ }^{-1}\right)$ and farmyard manure $\left(10 \mathrm{tha}^{-1}\right)$ were applied to field plols just before sowing.

Table 13. Effect of four pesticides on plant height and yield of groundnut (cv. 55-437) at Sadore, Niger, rainy season 1987 (from Subrahmanyam et al., 1988)

\begin{tabular}{|c|c|c|c|c|c|c|}
\hline \multirow[t]{3}{*}{ Treatment $^{\mathrm{a}}$} & \multicolumn{2}{|c|}{ Plant height $(\mathrm{cm})$} & \multicolumn{4}{|c|}{ Yield (t ha-1) } \\
\hline & \multirow[t]{2}{*}{ Irrigated } & \multirow[t]{2}{*}{ Rainfed } & \multicolumn{2}{|c|}{ Irrigated } & \multicolumn{2}{|c|}{ Rainfed } \\
\hline & & & Pods & Haulms & Pods & Haulms \\
\hline Dibromochloropropane & 32 & 15 & 3.85 & $3 \cdot 41$ & 1.86 & $1 \cdot 78$ \\
\hline Dazomet & 25 & 12 & $2 \cdot 89$ & 2.59 & $1 \cdot 10$ & 1.00 \\
\hline Carboíuran & 17 & 14 & $2 \cdot 50$ & 1.98 & 1.93 & 1.66 \\
\hline Aldicarb & 18 & 18 & 1.97 & $1 \cdot 71$ & $2 \cdot 25$ & 1.96 \\
\hline Control & 12 & 11 & $1 \cdot 19$ & 1.09 & 1.09 & 0.92 \\
\hline SE & \pm 2 & \pm 1 & $\pm 0 \cdot 33$ & \pm 0.33 & $\pm 0 \cdot 12$ & \pm 0.20 \\
\hline $\operatorname{CV}(\%)$ & 23 & 12 & 27 & 30 & 17 & 30 \\
\hline
\end{tabular}

"Dibromochtoropropane $\left(20 \mathrm{I}\right.$ in $85 \mathrm{I}$ of water/ha), carboluran $\left(6 \mathrm{~kg} \mathrm{a} . \mathrm{ha}^{-1}\right)$ and aldicarb $\left(4 \mathrm{~kg}\right.$ a.i ha $\left.\mathrm{h}^{-1}\right)$ were applied to the field plots on the day

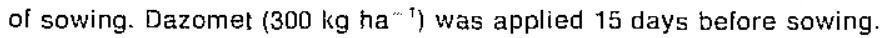


stem and pods per plant. Nodulation was good. Plants in control plots were stunted, chlorotic with severely necrosed root systems (Subrahmanyam et al., 1988).

Crop growth variability in groundnut in sandy soils of the Sahel seems to be largely due to parasitic nematodes and PCV. Rools invaded by nematodes become necrotic and may not be effective in utilizing available moisture and nutrients. Colonization by mycorrhiza and rhizobium is also drastically reduced. It is clear that crop growth variability in groundnut can be easily managed by soil application of some pesticides. It is interesting to note that both nematode populations and PCV incidence can be reduced using pesticides such as carbofuran. However, it is not economically feasible to control crop growth variability using pesticides for farmers in West Airrica. Further studies are required to determine the roles of these two biotic factors in crop growth variability. Agronomic practices such as crop rotation and tillage need to be tested to see if they affect crop growth variability.

\section{Conclusions}

1. Leaf spots, rust, rosette, and seedling diseases are responsible for considerable losses all over the groundnut producing regions of West Africa. In addition, aflatoxin contamination is a serious seedquality problem in West Africa. Crop growth variability is one of the major limiting factors of groundnut production in sandy soils of the Sahel.

2. The distribution of various diseases of groundnut needs to be determined through systematic disease surveys in various agroclimatic zones of the region to facilitate the identification of suitable locations for screening of germplasm and breeding lines for resistance to these diseases.

3. Combining resistance to these major diseases into agronomically acceptable varieties should receive high priority.

4. Seedling diseases can be controlled very effectively and economically by seed dressings. Hence, efforts to develop groundnut varieties with resistance to these diseases may not be required. Breeding for resistance to seedling diseases may also not be very successful, since a variely of fungi are associated with seedling diseases. Farmers should be advised to use good-quality seed for sowing and to apply seed protectant chemicals.

5. The levels of aflatoxin contamination in different geographical locations in West Africa need to be determined. There is a need to educate farmers in simple agronomic and cultural practices that are useful to reduce aflatoxin contamination. Research on transferring resistance to $A$. flavus invasion and/or aflatoxin production should be intensified.

6. Further testing of germplasm for stability of resistance to late leaf spot, rust, rosette and $A$. flavus should be carried out through multilocational trials in West Africa.

7. Studies on the alternative hosts of groundnut rosette viruses and spread of the disease by the principal vectors are necessary to understand the epidemiology of groundinut rosette and to formulate suitable management practices.

8. The distribution and economic importance of plant parasitic nematodes and of PCV in West Africa need to be determined. The relative importance of these two biotic factors in crop growth variability in groundnut in the Sahel needs to be established.

9. Suitable agronomic practices might be developed to reduce crop losses due to crop growth variability.

10. Cooperation between ICRISAT, IRHO, IIRSDA, ORSTOM (Institut Français de Recherche Scientifique pour le Développement en Cooperation), and Peanut CRSP (Collaborative Research Support Program) and the national programmes involved in the improvement of groundnut crop productivity in the region is essential for achieving these goals.

\section{References}

ANONYMOUS, 1982. Export polential surveys-AGC member countries. Part I. In Proceedings of the International Symposium in Africa on Production. World Oilseeds Market and IntraAfrican Trade in Groundnuts and Products, 7-11 June, Banjul, Gambia, pp. 52-86.

ANONYMOUS, 1987. World crop and livestock statistics 1948-1985. Area, yield and production of crops; production of livestock products. FAO Processed Statistics Series, 1, 294-296.

ATUAHENE-AMANKWA, G., HOSSAIN, M. A. and ASSIBI, M. A., 1988. Groundnut production and improvement in Ghana. Paper presented at the First Regional Meeting on Groundnut, 13-16 Seplember, ICRISAT Sahelian Center, Niamey, Niger.

BAUJARD, P., 1988. Maladies nématologiques pour la culture de I'arachide en Afrique de I'Ouest. Paper presented at the First Regional Meeting on Groundnut, 13-16 September, ICRISAT Sahelian Center, Niamey, Niger.

BOCK, K. R., 1987. Rosette and early leaf spot diseases: a review of research progress, 1984/85. In Proceedings of the Second Regional Groundnut Workshop for Southern Africa, ICRISAT, 10-14 February 1986, Harare, Zimbabwe, 5-14.

BOCKELEE-MORVAN, A. 1983. Les différentes variètés d'arachiderépartition gèographique el climatique disponibilité. Oléagineux, 38, 70-116.

BOOTE, K. J., JONES, J. W., MISHOE, J. W. and BERGER, R. D., 1983. Coupling parts to crop growth stimulators to predict yield reductions. Phytopathology, 73, 1581-1587.

CATHERINET, M., SAUGER, L. and DURAND, Y., 1954. Contribution à l'étude de la roselte chlorotique de l'arachide. Bulletin Agronomie France d'outre mer, 13, 163-180.

CUMMINS, D. G. and JACKSON, C. R., 1982. World peanut production, utilization and research. Special Publication no. 16. University of Georgia, College of Agrictiltural Experiment Station, Experiment, Georgia, USA, pp. 26-27.

DHERY, M. and GILLIER, P., 1971. Un nouveau pas dans la lutte contre la rosette de I'arachide. Oléagineux, 26, 243-251.

DOLLET, M., DUBERN, J., FAUQUET, C., THOUVENEL, J. C. and BOCKELEE-MORVAN, A., 1986. Groundnut viral diseases in West Africa. Tropical Agricultural Research Series no. 19. Tropical Agricultural Research Center, Ministry of Agriculture, Forestry and Fisheries, Japan, pp. 134-145.

EMECHEBE, A. M., 1980. A check-list of diseases of crops in the savanna and semi-arid areas of Nigeria. Samaru Miscellaneous Paper no. 100. Institute of Agricultural Research, Ahmadu Bello University, Samaru, Zaria, Nigeria, pp. 3-6.

FAUQUET, C. and THOUVENEL, J. C., 1980. Les maladies virales des plantes en Cöte d'voire. Editions de I'ORSTOM. Paris. 
GAUTREAU, J. and DE PINS, O., 1980. Groundnut production and research in Senegal. In Proceedings of the International Workshop on Groundnuts, 13-17 October. ICRISAT Center, Patancheru, AP, India, pp. 274-281.

GERMANI, G., 1981. Pathogenicity of the nematode Scutellenema cavenessi on peanut and soybean. Revue Nematologie, 4, 203-208.

GIBBONS, R. W., 1977. Groundnut rosette virus. In Diseases of Tropical Crops, (J. Kranz, J. Schutterer and W. Koch, Eds) (Berlin: Verlag Paul Parey), pp. 19-21.

GIBBONS, R. W. and MERCER, P. C., 1972. Peanut disease control in Malawi, Central Africa. Journal of American Peanut Research and Education Association, 4, 58-66.

GILLIER, P., 1978. Nouvelles limites des cultures d'arachides résistant à la secheresse el à la roselte. Oléagineux, 33, 25-28.

GILLIER, P. 1982. Influences on groundnul production in Wesl Africa. In Proceedings of the International Symposium in Africa on Production, World Oilseeds Market and Intra-African Trade in Groundnuts and Products, 7-11 June, Banjul, Gambia, pp. 111-129.

GILLIER, P. and BOCKELEE-MORVAN, A., 1975. Sèlection de l'arachide en vue de la résistance à la rosetle el à l'Aspergillus Hlavus. Séminaire d'Etude Agriculture et Hygiene des Plantes Centre de Recherches Agronomique, B.P. 5800, (Belgium: Gembloux), pp. 47-52.

HARKNESS, C. and SALAKO, E. A., 1982. Groundnut varieties and declined production in Nigeria. in Proceedings of the International Symposium in Africa on Production, World Oilseeds Market and Intra-Airican Trade in Groundnuts and Products, 7-11 June, Banjul, Gambia, pp. 299-314.

ICRISAT, 1987. ICRISAT West African programs annual report, ICRISAT Sahelian Center, BP 12404, Niamey, Niger, pp. 57-58.

IRHO (Institut de Recherches pour les Huiles el Olèagineux), 1986 , 1987. Fichiers d'expériences 1986 et 1987, Burkina Faso.

KHAN, E. F. and MISARI, S. M., 1987. Elfect of soil trealment with insecticides/nematicides on the seasonal development of plant parasitic nemalodes on groundnuls. Legumes and Oilseeds Research Program. Cropping Scheme Meeting 1987, institute of Agricultural Research, Ahmadu Bello University, Samaru, Zaria, Nigeria.

MCDONALD, D. 1966. Research on the aflatoxin problem in groundnuts in Northern Nigeria 1961-1966. Samaru Miscellaneous Paper No. 14, Institute of Agriculiural Research, Abmadu Bello University, Samaru, Zaria, Nigeria.

McDONALD, D., 1969a. Groundnut pod diseases. Review of Applied Mycology, 48, 465-474.

McDONALD, D., 1969b. Aspergillus flavus on groundnut (Arachis hypogaea L.) and its control in Nigeria. Journal of Stored Products Research, 5, 275-280.

McDONALD, D., 1978. The groundnut disease situation in northern Nigeria, May 1978. Institute of Agricultural Research, Ahmadu Bello University, Samaru, Zaria, Nigeria. Mimeograph.

McDONALD, D. and FOWLER, A. M., 1976. Control of Cercospora leaispot disease of groundnuts (Arachis hypogaea) in Nigeria. Nigerian Journal of Plant Protection, 2, 43-59.

MCDONALD, D. and HARKNESS, C., 1967. Aflatoxin in groundnut crops at harvest in northern Nigeria. Tropical Science, 9 , 148-161.

MCDONALD, D., SUBRAHMANYAM, P., GIBBONS, R. W. and SMITH, D. H., 1985. Early and late leaf spots of groundnut. Information Bulletin no. 21, ICRISAT Center, Patancheru, AP, India.

MEHAN, V. K. and MCDONALD, D., 1984. Research on the aflaloxin problem in groundnut at ICRISAT. Plant and Soil, 79, 255-260.

MEHAN, V. K., McDONALD, D. and GIBBONS, R. W., 1982. Seed colonization and aflatoxin production in groundnut genolypes inoculated with different strains of Aspergillus flavus. Oléagineux, 37 185-191.

MERNY, G., FORTUNER, R. and LUC, M., 1974. Les nematodes phytoparasites de Gambie. Agronomie Tropicale, 29, 702-707.

MISARI, S. M., BOYE-GONI, S. and KAIGAMA, B. K., 1988. Groundnut improvement, production, management and utilization in Nigeria: problems and prospects. Paper presented at the First
Regional Meeting on Groundnut, 13-16 September, ICRISAT Sahelian Center, Niamey, Niger.

MISARI, S. M., HARKNESS, C. and FOWLER, A. M., 1980. Groundnut production, utilization, research problems and future research needs in Nigeria. In Proceedings of the International Workshop on Groundnuts, 13-17 October, ICRISAT Center, Palancheru, AP, India, pp. 264-273.

MIXON, A. C., 1979. Developing groundnut lines with resislance to seed colonization by toxin-producing strains of Aspergillus species. PANS 25, 394-400

N'DIAYE, A., 1988. L'arachide au Sénégal: production, operations connexes et recherches. Paper presented at the First Regional Meeting on Groundnut. 13-16 September 1988, ICRISAT Sahelian Center, Niamey, Niger.

NIGAM, S. N., 1987. A review of the present slatus of the genetic resources of the ICRISAT Regional Groundnut Improvement Program, of the Southern African Cooperative Regional Yield Trials, and of rosette virus resistance breeding. In Proceedings of the Second Regional Groundnul Workshop for Southern Africa, ICRISAT, 10-14 February, Harare, Zimbabwe, pp. $15-30$.

PETTIT, R. E., 1985. Incidence of aflatoxin in groundnuts as influenced by seasonal changes in environmental conditions-a review. In Proceedings of the International Symposium on Agrometeorology of Groundnut, 21-26 August, ICRISAT Sahelian Center, Niamey, Niger, pp. 163-174.

PETTIT, R. E. and TABER, R. A., 1968. Faclors influencing aflatoxin accumulation in peanuts and the associated mycoflora. Applied Microbiology, 16, 1230-1234.

PICASSO, C., 1987. Aflatoxine, rosetle el rouille de l'arachide. Environnement climatique propice à leur présence el developpement. Oléagineux, 42, 25-33.

REDDY, D. V. R., 1984. Groundnut rosetle. In Compendium of Peanut Diseases, (D. M. Porter, D. H. Smith and R. Rodriguez-Kabana, Eds\}. American Phylopathological Society, St. Paul, MN, USA, pp. 49-50.

REDDY, L. J., NIGAM, S. N., DWIVEDI, S. L. and GIBBONS, R. W., 1987. Breeding groundnut cultivars resistant to rust (Puccinia arachidis Speg.). In Groundnut Rust Disease. Proceedings of a Discussion Group Meeting, 24-28 September 1984, ICRISAT Center, Patancheru, AP, India, pp. 17-23.

SALAKO, E. A., 1987. Summary of terminal report on groundnut pathology trials 1980-1986. Legumes and Oilseeds Research Program, Cropping Scheme Meeting 1987. Institute of Agricultural Research, Ahmadu Bello University, Samaru, Zaria, Nigeria.

SANKARA, P., 1987. The groundnut rust disease problem in Burkina Faso. In Groundnut Rust Disease. Proceedings of a Discussion Group Meeting, 24-28 September 1984, ICRISAT Center, Patancheru, AP, India, pp. 77-80.

SAVARY, S., 1985a. Comparaison de différentes techniques d'infection de folioles d'arachide par Puccinia arachidis Speg. Agronomie, 5, 325-329.

SAVARY, S., 1985b. Elfets du niveau de contamination et de la temperature sur quelques ètapes du cycle de Puccinia arachidis. Agronomie, 5, 479-485.

SAVARY, S., 1987a. Eludes épidémiologiques sur la rouille de I'arachide en Côte d'lvoire. Doctoral thesis, Agricultural University of Wageningen, The Netherlands.

SAVARY, S., 1987b. Enquête sur les maladies fongiques de I'arachide (Arachis hypogaea L.): I. Méthodes d'enquète el élude descriptive: les conditions de cultures et les principales maladies. Netherlands Journal of Plant Pathology, 93, 167-188.

SAVARY, S. and ZADOKS, J. C., 1989. Analyse des composantes de l'interaction hôte-parasite chez la rouille de l'arachide. II. Mesure de la résistance intermédiaire par un essai en micro-parcelles. Oleagineux, 44, 215-224.

SAVARY, S., NOIROT, M., BOSC, J. P. and ZADOKS, J. C., 1988 Peanut rust in West Africa: a new component in a multiple pathosystem. Plant Disease, 72, 1001-1009.

SMITH, D. H., 1984. Early and late leaf spots. In Compendium of Peanut Diseases, (D. M. Porter, D. H. Smith and R. 
Rodriguez-Kabana, Eds), American Phytopathological Socieły, St Paul, MN, USA, pp. 5-7.

SOUMANO, D. and DIALLO, D., 1982. Resuits of research work on varieties in Mali. In Proceedings of the International Symposium in Africa on Production, World Oilseeds Market and Intra-African Trade in Groundnuts and Products, 7-11 June, Banjul, Gambia, pp. 315-322.

SOUMANO, D. and TRAORE, S., 1988, Problemes et soins de recherche sur l'arachide au Mali. Paper presented at the First Regional Meeting on Groundnut, 13-16 September, ICRISAT Sahelian Center, Niamey, Niger.

SOUBRAHMANYAM, P. and McDONALD, D., 1982. Rusi disease of groundnut. Information Bulletin no. 13, ICRISAT Center, Palancheru, AP, india.

SUBRAHMANYAM, P. and McDONALD, D., 1987. Groundnut rust disease: epidemiology and control. in Groundnut Rust Disease. Proceedings of a Discussion Group Meeting, 24-28 September 1984. ICRISAT Center, Patancheru, AP, India, pp. 27-39.

SUBRAHMANYAM, P. and RAO, A. S. 1974. Occurrence of aflaloxins and citrinin in groundnut (Arachis hypogaea L.) at harvest in relation to pod condition and kernel moisture content. Current Science, 43, 707-710.

SUBRAHMANYAM, P., McDONALD, D., GIBBONS, R. W., NIGAM, S. N. and NEVILL, D. J., 1982. Resislance to rust and late leal spot diseases in some genotypes of Arachis hypogaea. Peanut Science, 9, 6-10.

SUBRAHMANYAM, P., HAMMONS, R. O., NIGAM, S. N., MCDONALD, D., GlBBONS, R. W. FAN, M. Y. and YEH, W. L., 1983. International cooperative screening for resistance of peanut to rust and late leai spot. Plant Disease, 67, 1108-1111.
SUBRAHMANYAM, P., REDDY, L. J., GIBBONS, R. W., and McDONALD, D., 1985. Peanut rust: a major threat to peanut production in the semiarid tropics. Plant Disease. 69, 813-819.

SUBRAHMANYAM, P., HASSANE, H., MOUNKAILA, A. and SMITH, D. H., 1988a. A groundnut rosette epidemic in Niger. International Arachis Newsletter, 3, 3-9.

SUBRAHMANYAM, P., NDUNGURU, B. J. and GREENBERG, D. C., 1988b. Elfects of pesticides and farmyard manure on crop-grow/h variability in groundnut. International Arachis Newsletter, 3, 9-10.

SUBRAHMANYAM, P., HASSANE, H., SMITH, D. H., MOUNKAILA, A. and NDUNGURU, B. J., 1989. Diseases of groundnut in Niger. Oléagineux (under review).

WALIYAR, F., McDONALD, D., SUBBA RAO, P. V. and REDDY, P. M., 1988. Biology and management of foliar diseases of groundnut (Project No. G-101(85)1C): Report of work carried out during September 1986 to December 1988. Legumes Pathology (Groundnut), Progress Report No. 3 (Restricted circulation).

YAYOCK, J. Y., ROSSEL, H. W. and HARKNESS, C., 1976. A review of the 1975 groundnut rosette epidemic in Nigeria. In Proceedings of the African Groundnut Symposium on Pests of Groundnuts and Millet in the Field, Kaolack, Senegal, 21-23 April, pp. 129-137.

ZAMBETTAKIS, C., BOCKELEE-MORVAN, A., WALIYAR, F. and ROSSION, J., 1977. Difíérences variétales de sensibilité de l'arachide à la contamination par A. flavus aux champs et en conditions artíficielles. Oléagineux, 32, 377-385.

ZIMMERMAN, A. 1907. Uber eine Krankheit der erdnusse (Arachis hypogaea). Pflazen, 3, 129-133. 